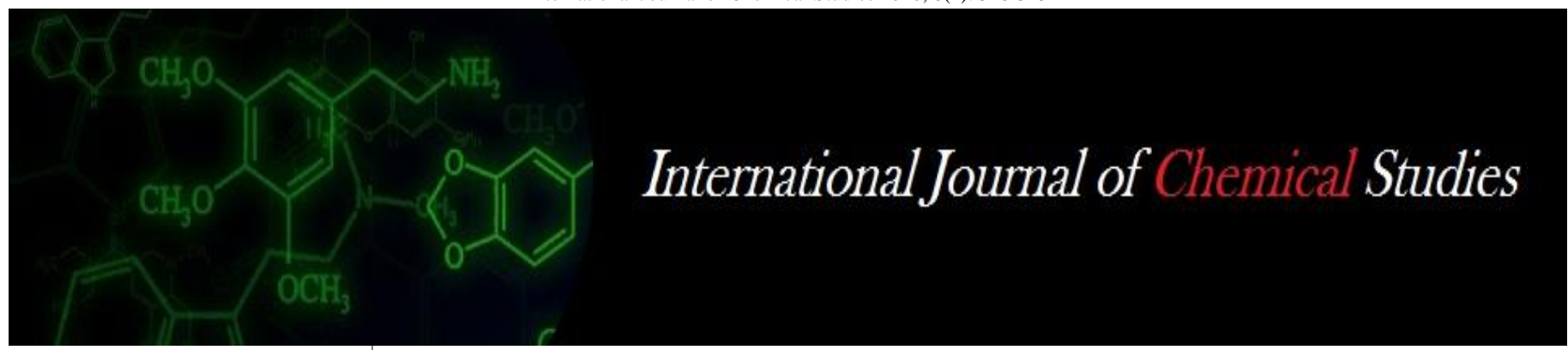

P-ISSN: 2349-8528

E-ISSN: 2321-4902

www.chemijournal.com

IJCS 2020; 8(4): 318-323

(C) 2020 IJCS

Received: 13-05-2020

Accepted: 15-06-2020

\section{Lopamudra Jena}

Department of Floriculture and

Landscaping, College of

Agriculture, OUAT,

Bhubaneswar, Odisha, India

Sanghamitra Pattnaik

Senior Scientist and Head, KVK,

Mayurbhanj, Odisha, India
Corresponding Author: Lopamudra Jena

Department of Floriculture and

Landscaping, College of

Agriculture, OUAT,

Bhubaneswar, Odisha, India

\section{Impact of nutrient management on yield and yield attributing traits of gerbera (Gerbera jamesonii L.) growing under protection}

\section{Lopamudra Jena and Sanghamitra Pattnaik}

\author{
DOI: https://doi.org/10.22271/chemi.2020.v8.i4e.9708
}

\begin{abstract}
Gerbera is a flower of choice which is grown widely all across the world. Though quality accounts utmost importance beside quantity therefore feeding the plants with balanced combination and concentration of both major and micronutrients is a must. The present experiment entitled "Impact of nutrient management on yield and yield attributing traits of Gerbera (Gerbera jamesonii L.) growing under protection" was executed under polyhouse condition. This experiment was conducted following Randomised Block Design with three replications \& twelve treatments including a control. Result of the investigation envisaged that the nutrient combination NPK 20:20:20@15g/10 ltr + Multiplex General Liquid @ $0.2 \%\left(\mathrm{~T}_{12}\right)$ performed best for the parameters like plant height $(31.87 \mathrm{~cm})$, leaf area $(204.53$ $\left.\mathrm{cm}^{2}\right)$, flower stalk length $(46.50 \mathrm{~cm})$, diameter of flowering head $(10.84 \mathrm{~cm})$, vase life of cut flowers (6.70 days) and chlorophyll content of leaves (73.02). However, the plants treated with NPK 20:20:20 @ 15g/10 ltr + Power Bio-20 @0.2\% ( $\left.\mathrm{T}_{11}\right)$ exhibited significant increase in parameters like number of leaves per plant (37.67), number of suckers per plant (3.20), flower stalk diameter $(5.70 \mathrm{~mm})$ and flower neck diameter (3.45mm). On the other hand, the nutrient combination NPK 20:20:20 @15g/10 1tr + $\mathrm{ZnSO}_{4} @ 0.2 \%+\mathrm{MnSO}_{4} @ 0.2 \%\left(\mathrm{~T}_{6}\right)$ resulted in maximum plant spread $(54.53 \mathrm{~cm})$ and number of flowers per plant (3.63).
\end{abstract}

Keywords: Nutrient management, gerbera, protection, major nutrients, micronutrients

\section{Introduction}

Gerbera is a very popular high value cut flower crop grown worldwide. It is not only popular among the flower lovers, amateur gardeners etc but also among commercial growers due to their huge demand in flower markets. The attractive flowers are available in various colours. It is mostly preferred among commercial growers because of its wide range of colour variation, long lasting behaviour and wider adaptability for culture which have made Gerbera a flower of choice for cultivation in India. In the International cut flower trade it ranks fourth position next to rose, carnation\& chrysanthemum.

Gerbera (Gerbera jamesonii L.) a member of family Asteraceae is native to South Africa more particularly Transvaal province \& Asiatic regions. The genus comprises of around 45 species. In India, about 7 species are recorded which are distributed in the temperate regions of Himalayas from Kashmir to Nepal at altitudes of 1300-3200 meters. Out of all the recorded species viz. Gerbera asplenifolia, Gerbera aurantiaca, Gerbera Jamesonii, Gerbera kunzeana, Gerbera viridifolia etc. Only Gerbera Jamesonii is under cultivation.

Gerbera is treated as a very popular cut flower in Holland, Germany \& USA (Choudhary and Prasad, 2000 ${ }^{[3]}$ and Sujatha et al., 2002 $\left.{ }^{[15]}\right)$. However, in India, the commercial cultivation is confined to Maharashtra, Karnataka, Tamil Nadu, West Bengal, Jammu \& Kashmir, Andhra Pradesh, parts of Sikkim, Meghalaya, Nagaland, Uttarakhand etc where efforts are made to produce excellent quality cut flowers for domestic as well as international markets. Tropical Floritech Pvt. Ltd. in Bangalore has emerged as a leading player in the commercial cultivation of gerbera in India.

The increased demand for good quality cut gerbera for local as well as international trade can be successfully met through meeting the inherent demand of the crop. It can be made possible through growing gerbera plants under protection which ensures year round production by protecting the plants from external vagaries and providing the plants with balanced 
combination and concentration of major nutrients along with micronutrients, which not only increase the cumulative yield but also enhance the quality of cut flowers in gerbera fetching higher price in market in return. The present investigation aims at studying the effect of nutrient management on various vegetative and floral parameters as well as various quality attributes having following objectives-

1. Impact of nutrients application on vegetative growth of gerbera.

2. Impact of nutrients application on flower yield and quality of gerbera.

3. Influence of nutrient application on vase life of Gerbera.

4. Effect of applied nutrients on chlorophyll content of Gerbera leaves.

\section{Materials and Methods}

The present study on Impact of nutrient management on yield and yield attributing traits of Gerbera (Gerbera jamesonii L.) growing under protection executed during 2018-19 at the Horticultural Research Station, College of Agriculture, OUAT, Bhubaneswar, Odisha. It was conducted to study the effect of various micronutrients on vegetative growth and flowering of Gerbera (Gerbera jamesonii L.) cv. Stanza. In this experiment, various micronutrients either single or in combinations along with RDF were taken for foliar application along with a control plot. Three commercial formulations of micronutrients were used in this investigation namely Toto Care, Power Bio-20 and Multiplex General Liquid. The entire experimental area was laid out in Randomised Block Design (RBD) consisting up of 3 replications, where each replication comprised of 13 treatments viz.

\section{$\mathrm{T}_{1}$ : NPK 20:20:20@15g/10 ltr (Control)}

$\mathrm{T}_{2}$ : NPK 20:20:20@15g/10 ltr + $\mathrm{ZnSO}_{4}(0.2 \%)$

$\mathrm{T}_{3}$ : NPK 20:20:20@15g/10 ltr + Borax $(0.2 \%)$

$\mathrm{T}_{4}$ : NPK 20:20:20 @ 15g/10 ltr $+\mathrm{MnSO}_{4}(0.2 \%)$

$\mathrm{T}_{5}$ : NPK 20:20:20@15g/10 ltr $+\mathrm{ZnSO}_{4}(0.2 \%)+$ Borax $(0.2 \%)$

$\mathrm{T}_{6}$ : NPK 20:20:20@15g/10 ltr $+\mathrm{ZnSO}_{4}(0.2 \%)+\mathrm{MnSO}_{4}$ $(0.2 \%)$

$\mathrm{T}_{7}$ : NPK 20:20:20@15g/10 ltr + Borax $(0.2 \%)+\mathrm{MnSO}_{4}$ $(0.2 \%)$

$\mathrm{T}_{8}$ : NPK 20:20:20@15g/10 ltr $+\mathrm{ZnSO}_{4}(0.1 \%)+$ Borax $(0.1 \%)+\mathrm{MnSO}_{4}(0.1 \%), \mathrm{T}_{9}: \mathrm{NPK} 20: 20: 20 @ 15 \mathrm{~g} / 10 \mathrm{ltr}+$ $\mathrm{ZnSO}_{4}(0.2 \%)+\operatorname{Borax}(0.2 \%)+\mathrm{MnSO}_{4}(0.2 \%), \mathrm{T}_{10}$ : NPK 20:20:20@15g/10 ltr + Toto Care (0.2\%)

$\mathrm{T}_{11}$ : NPK 20:20:20 @ 15g/10 ltr + Power Bio-20 (0.2\%)

$\mathrm{T}_{12}$ : NPK 20:20:20@15g/10 ltr + Multiplex General Liquid $(0.2 \%)$.

Chemical composition of commercial micronutrient mixtures used in this experiment

Toto Care: $\mathrm{Zn}(3.6 \%), \mathrm{Fe}(6.6 \%), \mathrm{Mn}(4.3 \%), \mathrm{Cu}(0.8 \%)$ and B $(0.7 \%)$

Power Bio-20: NPK+ Mg (1\%), Fe EDTA (960 mg), Mn (480 mg), Cu (480 mg), Zn (480 mg), B (190 mg), Co (8 mg), Mo (8 mg)

Multiplex General Liquid: $\mathrm{Zn}$ (3.0\%), $\mathrm{Mg}(0.2 \%), \mathrm{Fe}$ (0.2\%), Mn (0.2\%), Cu (0.1\%), Mo (0.005\%)

The foliar application of RDF (NPK 20:20:20 @ 15g/10 ltr) was done weekly interval while micronutrients were sprayed fortnightly i.e. once in 15 days. Observations for vegetative parameters were taken for plant height $(\mathrm{cm})$, plant spread $(\mathrm{cm})$, number of leaves per plant, leaf area $\left(\mathrm{cm}^{2}\right)$ \& number of suckers per plant; for flowering traits were taken for flower stalk length $(\mathrm{cm})$, diameter of flowering head $(\mathrm{cm})$, number of flowers per plant, flower stalk diameter $(\mathrm{cm})$, neck diameter $(\mathrm{cm})$ and vase life (days); for biochemical parameter observation was taken on chlorophyll content of leaves by using the measuring instrument called spadmeter.

\section{Result and Discussion}

Results of the findings revealed that foliar application of major nutrients in combination with micronutrients significantly enhanced several vegetative characters as well as flowering traits.

\section{Vegetative characters \\ Plant height $(\mathbf{c m})$}

Plant height was recorded to be maximum $(31.87 \mathrm{~cm})$ under the treatment combination $\mathrm{T}_{12}$ (NPK 20:20:20@15g/10 ltr + Multiplex general liquid @ $0.2 \%$ ) found to be significantly different from all other treatments. However minimum plant height $(27.40 \mathrm{~cm})$ was recorded in the control i.e. $\mathrm{T}_{1}$ (NPK 20:20:20@15g/10 ltr).

The increased plant height was attributed because of foliar application of Multiplex General Liquid which is having micronutrient elements those are responsible for nitrogen metabolism that stimulates the vegetative growth thus resulting in increased plant height. They also activate the enzyme IAA oxidase which oxidizes IAA in plants which is responsible for apical dominance leading to increased plant height. By serving as a catalyst, the micronutrient elements alter the enzymatic reactions and helps in larger biosynthesis of photosynthetic assimilates which is another for enhanced plant height.

Similar results were obtained by Bhagyalakshamamma (2014) [1] in gerbera where foliar application of Multiplex general liquid contributed maximum plant height.

\section{Plant spread (cm)}

Maximum plant spread $(54.53 \mathrm{~cm})$ was recorded under the treatment combination $\mathrm{T}_{6}$ (NPK 20:20:20 @ 15g/10 ltr + $\left.\mathrm{ZnSO}_{4} @ 0.2 \%+\mathrm{MnSO}_{4} @ 0.2 \%\right)$. The lowest value of plant spread $(45.80 \mathrm{~cm}$ ) was recorded under control (NPK 20:20:20 @ 15g/10 ltr).

The foliar application of $\mathrm{Zn}$ is responsible for improved root system thus promoting better absorption \& utilization of water and nutrients derived from the soil. $\mathrm{Mn}$ is also known to activate enzymes like carbonic dehydrogenase, catalase and tryptophan synthase which favour various physiological activities that contribute to the cell division, cell multiplication and cell differentiation resulting in enhanced plant spread.

Above result also comes in line with the experimental findings reported by Sahu et al. (2017) ${ }^{[13]}$ in gerbera, where plant spread was found to be highest $(45.20 \mathrm{~cm})$ when the plants were sprayed with $0.2 \%$ each of $\mathrm{ZnSO}_{4} \& \mathrm{MnSO}_{4}$.

\section{Number of leaves per plant}

The treatment combination $\mathrm{T}_{11}$ (NPK 20:20:20 @ 15g/10 ltr + Power Bio-20@0.2\%) recorded maximum (37.67) number of leaves per plant. On the other hand the minimum number of leaves i.e. 28.80 was noted in control plot $\left(\mathrm{T}_{1}\right)$.

Power Bio- 20 is a commercial micronutrient formulation which consists of $\mathrm{Mg}, \mathrm{Fe}, \mathrm{Mn}, \mathrm{Cu}, \mathrm{B}, \mathrm{Zn}, \mathrm{Co} \& \mathrm{Mo} . \mathrm{Mn}$ is responsible for carbohydrate and nitrogen metabolism thus 
helping in $\mathrm{CO}_{2}$ assimilation in photosynthesis, resulting in improved plant growth \& ultimately increase the number of leaves. Boron is crucial for regulation of meristematic tissue cell synthesis thus helping in cell division \& differentiation resulting in increased leaf number. Iron helps in photosynthesis and translocation of photosynthates produced imparting better growth and thereby increase the number of leaves per plant.

This result can be supported by the research findings of Chaturvedi et al. (1986) ${ }^{[2]}$ who reported that application of Agromin (2\% N + chelated form of $\mathrm{Mn}, \mathrm{Mg}, \mathrm{B}, \mathrm{Zn}, \mathrm{Fe}, \mathrm{Cu}$ and Mo) significantly increased number of leaves in gladiolus.

\section{Leaf area $\left(\mathrm{cm}^{2}\right)$}

From the current experiment it is evident that foliar application of macro \& micro nutrient combinations significantly influenced the leaf area \& maximum improvement was noticed under $\mathrm{T}_{12}$ (NPK 20:20:20 @ 15g/10 ltr + Multiplex general liquid @0.2\%). However, in control, plants receiving NPK 20:20:20 @ 15g/10 ltr recorded minimum leaf area $\left(160.33 \mathrm{~cm}^{2}\right)$ as compared to others.

Foliar application of micronutrients plays stimulative effect on loosening cell wall, thereby increasing cell elongation along with cell differentiation \& enlargement. It accounts increase in leaf area. Similarly, micronutrients are also known to play vital role in increasing photosynthesis \& translocation of the manufactured food materials that may result in enhanced leaf area.

This result also comes in line with the experimental findings reported by Tyagi et al. $(2011)^{[16]}$ where maximum leaf area $\left(178.88 \mathrm{~cm}^{2}\right)$ in gerbera was registered when the plants were applied with the treatment combination consisting of $75 \%$ $\mathrm{RDF}+0.15 \%$ each of $\mathrm{ZnSO}_{4}, \mathrm{MnSO}_{4} \& \mathrm{FeSO}_{4}$.

\section{Number of suckers per plant}

During the course of investigation it was depicted that highest no. of suckers were produced under the treatment combination $\mathrm{T}_{11}$ (NPK 20:20:20 @ 15g/10 ltr + Power Bio-20 $@ 0.2 \%)$. Control receiving foliar application of only major nutrients produced minimum no. of suckers (2.07).

The increase in no. of suckers might be due to various micronutrients which play important role in nitrogen metabolism thus resulting in more vegetative growth and suckers production. Micronutrients, for being essential components of several enzymes such as dehydrogenase, peptidase, proteinase etc. Promote growth hormones those are closely associated with excellent growth and sucker production. They are also known to enhance photosynthesis \& translocation of food materials that are necessary for production of more number of suckers.

This result also comes in conformity with the findings of Sirin (2011) ${ }^{[14]}$ who reported highest no. of daughter plants $(3.53$ per plant) in gerbera with the application of "Çolakoglu-2" nutrient solution.

Table 1: Impact of nutrients on vegetative characters of gerbera

\begin{tabular}{|c|c|c|c|c|c|c|}
\hline SI No. & Treatments & $\begin{array}{l}\text { Plant height } \\
(\mathbf{c m})\end{array}$ & $\begin{array}{l}\text { Plant spread } \\
(\mathrm{cm})\end{array}$ & $\begin{array}{c}\text { Number of } \\
\text { leaves per plant }\end{array}$ & $\begin{array}{l}\text { Leaf area } \\
\qquad\left(\mathrm{cm}^{2}\right)\end{array}$ & $\begin{array}{c}\text { Number of suckers } \\
\text { per plant }\end{array}$ \\
\hline 1 & $\mathrm{~T}_{1}$ & 27.40 & 45.80 & 28.80 & 160.33 & 2.07 \\
\hline 2 & $\mathrm{~T}_{2}$ & 28.93 & 54.63 & 37.33 & 189.87 & 3.00 \\
\hline 3 & $\mathrm{~T}_{3}$ & 27.60 & 48.27 & 33.13 & 179.67 & 2.29 \\
\hline 4 & $\mathrm{~T}_{4}$ & 27.87 & 49.90 & 32.13 & 181.93 & 2.40 \\
\hline 5 & $\mathrm{~T}_{5}$ & 27.87 & 47.87 & 33.67 & 186.07 & 2.44 \\
\hline 6 & $\mathrm{~T}_{6}$ & 29.27 & 54.53 & 37.47 & 197.13 & 2.53 \\
\hline 7 & $\mathrm{~T}_{7}$ & 27.33 & 47.43 & 31.13 & 183.67 & 2.38 \\
\hline 8 & $\mathrm{~T}_{8}$ & 29.13 & 51.33 & 34.33 & 194.67 & 2.45 \\
\hline 9 & $\mathrm{~T}_{9}$ & 27.53 & 48.17 & 36.53 & 187.27 & 2.60 \\
\hline 10 & $\mathrm{~T}_{10}$ & 28.27 & 50.13 & 33.87 & 196.27 & 2.47 \\
\hline 11 & $\mathrm{~T}_{11}$ & 29.67 & 51.53 & 37.67 & 195.07 & 3.20 \\
\hline 12 & $\mathrm{~T}_{12}$ & 31.87 & 51.80 & 36.93 & 204.53 & 2.73 \\
\hline $\mathrm{SE}(\mathrm{m}) \pm$ & & 0.692 & 1.288 & 1.136 & 4.405 & 0.159 \\
\hline C.D. at $5 \%$ & & 2.043 & 3.802 & 3.355 & 13.002 & 0.469 \\
\hline
\end{tabular}

\section{Flowering traits}

\section{Flower stalk length (cm)}

From the executed experiment it was revealed that plants producing flowers with highest stalk length were reported under $\mathrm{T}_{12}$ (NPK 20:20:20@15g/10 ltr + Multiplex general liquid@0.2\%). However, the lowest stalk length $(43.78 \mathrm{~cm})$ was recorded in the control plot receiving only major nutrients.

The increment in flower stalk length may be attributed due to $\mathrm{Zn}$, which helps in accumulation of photosynthetic assimilates necessary for increase in stalk length. Iron is known to be involved in synthesis of plant hormones that influence the stalk length. Micronutrients also play pivotal role in enhancing cell division and enlargement, improve protein synthesis and dry matter accumulation thus promoting the apical dominance which may be another reason of increased stalk length.

The result comes in agreement with finding of El- Naggar (2009) ${ }^{[4]}$, who reported maximum floral stem length in carnation resulted by foliar fertilization with "Sangral" containing Fe, Zn, Cu, B and Mo. Nagaraju et al. (2003) [11] also reported that Multiplex application resulted in increased stem length in rose.

\section{Diameter of flowering head $(\mathrm{cm})$}

It is a qualitative parameter considered essential for domestic as well as international market. From the investigation, it was inferred that maximum diameter of flowering head was registered in $\mathrm{T}_{12}$ (NPK 20:20:20@15g/10 1tr + Multiplex general liquid @0.2\%). The control plot showed lowest flower head diameter i.e. $9.49 \mathrm{~cm}$.

It may be due to foliar application of micronutrients those are responsible for production of more food materials that leads to increased diameter of flowering head.

This result was supported by the findings of El- Naggar (2009) ${ }^{[4]}$ as he reported maximum flower diameter in carnation by application of nutrient formulation "Sangral". The result also comes in conformity with the findings of 
Nagaraju et al. (2003), where fertilization with Multiplex recorded highest bud diameter in rose.

\section{Number of flowers/plant}

The gerbera plants receiving the treatment combination $\mathrm{T}_{6}$ (NPK 20:20:20@15g/10 ltr $+\mathrm{ZnSO}_{4} @ 0.2 \%+\mathrm{MnSO}_{4}$ @ $0.2 \%$ ) are noticed to produce maximum number of flowers per plant. Besides, plants under control receiving NPK 20:20:20@15g/10 ltr only recorded minimum no. of flowers per plant viz. 2.20 nos.

The nutrient element Zinc is responsible for the carbohydrate metabolism and helps in higher assimilate synthesis which may serve as a reason for increased flower production. Similarly Manganese is essential for chlorophyll formation thus promotes the photosynthetic process resulting in production of more photosynthates. By utilizing those food reserves, plants go for production of more no. of flowers ultimately boosting up the total flower yield.

This result collaborates with findings reported by Jitendra $e t$ al. (2003) ${ }^{[5]}$ in carnation where foliar application of $\mathrm{Zn} \& \mathrm{Mn}$ registered maximum flowering in plants.

\section{Flower stalk diameter $(\mathrm{cm})$ -}

From the executed experiment, flower stalk diameter was found to be maximum in the treatment combination $\mathrm{T}_{11}$ (NPK 20:20:20@15g/10 ltr + Power Bio-20@0.2\%). Minimum flower stalk diameter $(4.88 \mathrm{~mm})$ was observed in the plants of control plot receiving major nutrients only.

The increment in flower stalk diameter may be due to enhanced photosynthetic activity resulting in more food matter production which is attributed by the application of nutruient combinations. Micronutrients are also responsible for stimulating cell wall division \& cell wall differentiation through many enzymatic activities which in turn impart better flower stalk diameter.

This result can be supported by the findings of Khoshgoftarmanesh et al. (2008) ${ }^{[7]}$ who got maximum flower stem thickness by applying iron $(\mathrm{Fe})$, zinc $(\mathrm{Zn})$, manganese $(\mathrm{Mn})$, and copper $(\mathrm{Cu})$ in several combinations on three Rose cultivars.

\section{Flower neck diameter $(\mathrm{cm})$}

The treatment effects regarding the flower neck diameter were found to be varied significantly, where the treatment combination $\mathrm{T}_{11}$ (NPK 20:20:20@15g/10 ltr + Power Bio$20 @ 0.2 \%$ ) resulted in maximum neck diameter of the flowering stalk. However lowest flower neck diameter (2.90 $\mathrm{mm}$ ) was recorded in control $\left(\mathrm{T}_{1}\right)$.

This may be because of the availability of micronutrients through foliar application to the plants, those serve in carrying out of various metabolic activities properly resulting in thicker neck diameter of the flowering stalk. In some other investigations, the thick neck diameter was mentioned to be the result of Zinc which is responsible for tryptophan biosynthesis, a precursor of Auxin (IAA) \& also helps in protein synthesis which may lead to thicker neck diameter of the flower stalk.

This result comes in conformity with the research findings of Naik et al. (2007) ${ }^{[12]}$ in rose cv. Grandagala and cv. Carvette, where combined application of Boron $(0.2 \%)+\mathrm{Cu}(0.20 \%)+$ $\mathrm{Fe}(1 \%)+\mathrm{Mn}(1 \%)$ and $\mathrm{Zn}(1 \%)$ recorded maximum neck diameter.

\section{Impact of nutrients on vase life of cut flowers (days)}

The data pertaining to the vase life of cut flower of gerbera revealed that maximum vase life was found with the flowers, those received the treatment combination $\mathrm{T}_{12}$ (NPK 20:20:20 @15g/10 ltr + Multiplex general liquid @0.2\%). On the other hand minimum vase life (4.63 days) of cut gerbera was inferred in control $\left(\mathrm{T}_{1}\right)$ receiving the treatment combination NPK 20:20:20 @15g/10 ltr.

The micronutrient application in foliar form is known to play crucial role in the photosynthesis process, thereby enhancing the stored carbohydrate reserve which may serve as a prominent reason for prolonged vase life. On the other hand, flowers with better stem and neck diameter, resulted through various physiological \& metabolic activities are also found to remain fresh for long period.

This result comes in line with the experimental findings reported by Kewate and Sable (1997) ${ }^{[6]}$ in rose cv. Paradise \& Muthumanicham et al. (1999) ${ }^{[10]}$ in gerbera.

\section{Biochemical parameter \\ Impact of nutrients on chlorophyll content of leaves}

Foliar application of different nutrient combinations on gerbera exhibited significant influence on the chlorophyll content of the leaves which was measured with the help of a measuring tool called as spadmeter. From the data concerning chlorophyll content of gerbera leaves it was revealed that the nutrient combination $\mathrm{T}_{12}$ (NPK 20:20:20 @15g/10 ltr + Multiplex general liquid @ $0.2 \%$ ) resulted in plants exhibiting maximum chlorophyll content. The leaf chlorophyll content of gerbera plants were found to be minimum i.e. 56.07 in control plot applied with $\mathrm{T}_{1}$ (NPK 20:20:20 @ 15g/10 ltr).

This increased chlorophyll content in leaves may be accounted due to the foliar application of commercial formulation Multiplex general liquid containing $\mathrm{Zn}, \mathrm{Mn}, \mathrm{Cu}$, $\mathrm{Fe} \& \mathrm{~B}$. Iron acts as catalyst for enhancing synthesis of chlorophyll molecule. Iron being an important nutrient element is actively involved in the compound protophyrin ring which leads to chlorophyll formation. Manganese is also reported to platy vital role in chlorophyll formation thereby increasing the leaf chlorophyll content. On the other hand, Molybdenum also helps in nitrogen metabolism thus helping in the synthesis of chlorophyll molecule.

Similar results are also reported by Kumar et al. (2004) ${ }^{[8]}$ in tuberose cv. Double and Mostafa et al. (1997) [9] in chrysanthemum. 


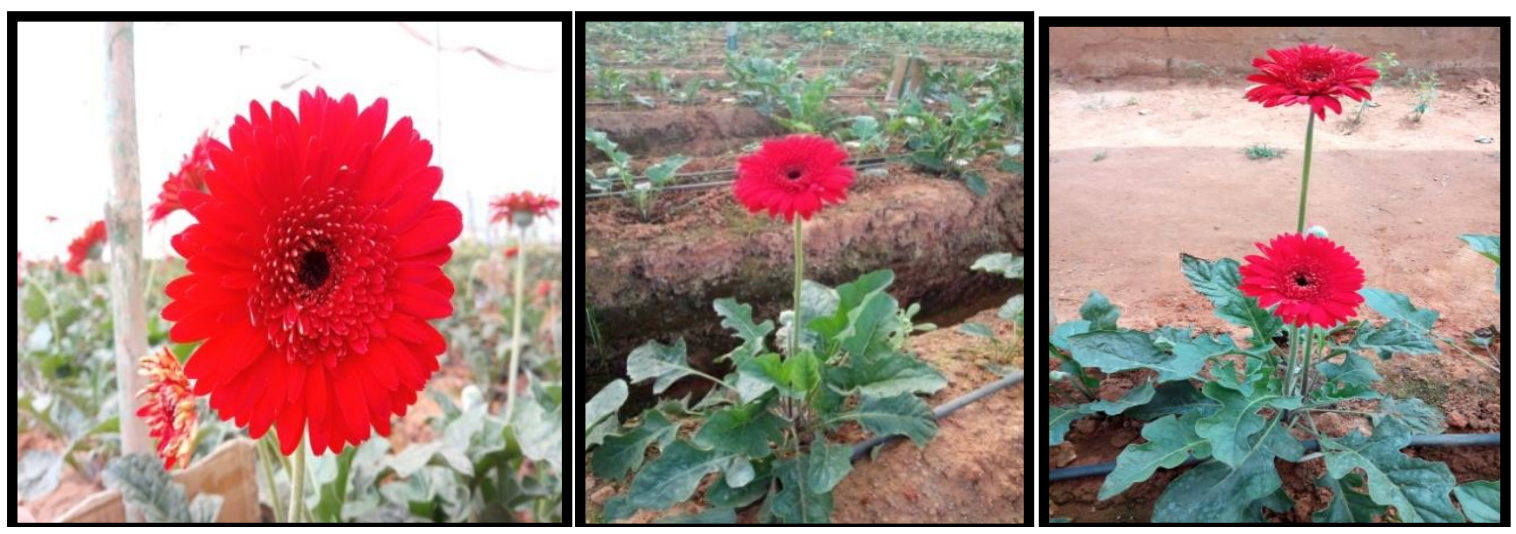

Fig 1: Gerbera cv. Stanza taken for the investigation

Table 2: Impact of nutrients on flowering traits of gerbera

\begin{tabular}{|c|c|c|c|c|c|c|c|}
\hline SI No. & Treatments & $\begin{array}{c}\text { Flower stalk } \\
\text { length }(\mathbf{c m})\end{array}$ & $\begin{array}{c}\text { Diameter of } \\
\text { flowering head }(\mathbf{c m})\end{array}$ & $\begin{array}{c}\text { Number of } \\
\text { flowers per plant }\end{array}$ & $\begin{array}{c}\text { Flower stalk } \\
\text { diameter }(\mathbf{c m})\end{array}$ & $\begin{array}{c}\text { Flower neck } \\
\text { diameter }(\mathbf{c m})\end{array}$ & $\begin{array}{c}\text { vase life of cut } \\
\text { flowers }(\mathbf{d a y s})\end{array}$ \\
\hline 1 & $\mathrm{~T}_{1}$ & 42.11 & 9.49 & 2.20 & 4.88 & 2.90 & 4.63 \\
\hline 2 & $\mathrm{~T}_{2}$ & 44.88 & 10.33 & 2.40 & 5.04 & 3.11 & 6.53 \\
\hline 3 & $\mathrm{~T}_{3}$ & 43.78 & 10.23 & 2.43 & 5.18 & 3.18 & 5.40 \\
\hline 4 & $\mathrm{~T}_{4}$ & 42.46 & 10.37 & 2.27 & 5.17 & 3.12 & 5.03 \\
\hline 5 & $\mathrm{~T}_{5}$ & 42.92 & 10.27 & 2.54 & 5.15 & 2.98 & 5.20 \\
\hline 6 & $\mathrm{~T}_{6}$ & 44.91 & 10.23 & 3.63 & 5.33 & 3.38 & 5.83 \\
\hline 7 & $\mathrm{~T}_{7}$ & 45.44 & 10.51 & 2.38 & 5.08 & 3.03 & 5.17 \\
\hline 8 & $\mathrm{~T}_{8}$ & 45.25 & 10.74 & 2.99 & 5.42 & 3.39 & 5.50 \\
\hline 9 & $\mathrm{~T}_{9}$ & 44.76 & 10.20 & 2.77 & 5.10 & 3.05 & 5.57 \\
\hline 10 & $\mathrm{~T}_{10}$ & 45.89 & 10.37 & 3.13 & 5.50 & 3.43 & 5.68 \\
\hline 11 & $\mathrm{~T}_{11}$ & 45.73 & 10.53 & 3.36 & 5.70 & 3.45 & 6.07 \\
\hline 12 & $\mathrm{~T}_{12}$ & 46.50 & 10.84 & 3.50 & 5.18 & 3.23 & 6.70 \\
\hline SE(m) \pm & & 0.383 & 0.247 & 0.269 & 0.122 & 0.074 & 0.311 \\
\hline C.D. at $5 \%$ & & 1.130 & 0.728 & 0.794 & 0.361 & 0.218 & 0.919 \\
\hline
\end{tabular}

Table 3: Impact of nutrients on chlorophyll content of gerbera leaves

\begin{tabular}{|c|c|c|}
\hline SI No. & Treatments & Chlorophyll content of leaves \\
\hline 1 & $\mathrm{~T}_{1}$ & 56.07 \\
\hline 2 & $\mathrm{~T}_{2}$ & 63.61 \\
\hline 3 & $\mathrm{~T}_{3}$ & 60.99 \\
\hline 4 & $\mathrm{~T}_{4}$ & 64.65 \\
\hline 5 & $\mathrm{~T}_{5}$ & 64.02 \\
\hline 6 & $\mathrm{~T}_{6}$ & 63.26 \\
\hline 7 & $\mathrm{~T}_{7}$ & 61.17 \\
\hline 8 & $\mathrm{~T}_{8}$ & 67.92 \\
\hline 9 & $\mathrm{~T}_{9}$ & 70.79 \\
\hline 10 & $\mathrm{~T}_{10}$ & 66.79 \\
\hline 11 & $\mathrm{~T}_{11}$ & 60.11 \\
\hline 12 & $\mathrm{~T}_{12}$ & 73.02 \\
\hline SE(m) \pm & & 2.694 \\
\hline C.D. at $5 \%$ & & 7.951 \\
\hline
\end{tabular}

\section{Conclusion}

Based on the results derived from the present investigation foliar application of several nutrient elements in combination exhibited significant improvements concerning various vegetative and floral parameters along with vase life of cut flowers \& chlorophyll content of gerbera leaves. However, best performance on parameters like plant height, leaf area, flower stalk length, diameter of flowering head, vase life of cut flowers \& chlorophyll content of leaves was attributed by the foliar application of NPK 20:20:20 @15g/10 ltr + Multiplex general liquid @0.2\% $\left(\mathrm{T}_{12}\right)$. Besides, most promising results regarding number of leaves per plant, number of suckers per plant, flower stalk diameter \& flower neck diameter were obtained by foliar application of NPK 20:20:20@15g/10 ltr + Power Bio-20@0.2\%( $\left.\mathrm{T}_{11}\right)$.The nutrient combination NPK 20:20:20@15g/10 ltr + $\mathrm{ZnSO}_{4} @ 0.2 \%+$ $\mathrm{MnSO}_{4} @ 0.2 \%\left(\mathrm{~T}_{6}\right)$ gave best performance on parameters like plant spread \& number of flowers per plant. In contrast to this, control plot $\left(T_{1}\right)$ receiving NPK 20:20:20 @15g/10 1tr only recorded minimum of above said parameters.

\section{References}

1. Bhagyalakakshmamma BS. Effect of micronutrient formulations on growth, yield, quality and post harvest life of gerbera under cover. M.Sc. thesis submitted to UAS, Bangalore, 1998.

2. Chaturvedi OP, Shukla IN, Singh AR. Effect of Agromin on growth and flowering in gladiolus. Programme Horticulture. 1986; 18(3, 4):196-199.

3. Choudhary A, Prasad CA. Effect of potassium and calcium concentrations in the nutrient solution on growth and nutrient uptake of rose plants. International Journal of Scientific Research. 2000; 69(4):606-608.

4. EL-Naggar. Response of Dianthes caryophyllus L. plants to foliar nutrition. World journal of Agricultural Science. 2009; 5(5):622-630.

5. Jitendra K, Mir A, Singh PV. Effect of Mn and Zn spray on carnation. Journal of Ornamental Horticulture. 2003; 6(1):83.

6. Kewate M, Sable AS. Influence of growth regulators and foliar nutrients on vase life, grading and economics of rose cv. Paradise. Journals of soil and crops. 1997; 7(1):96-98.

7. Khoshgoftarmanesh $\mathrm{AH}$, Khademi H, Hosseini $\mathrm{F}$, Aghajani R. Influence of additional micronutrient supply on growth, nutritional status and flower quality of three 
rose cultivars in a soilless culture. Journal of Plant Nutrition. 2008; 31(9):1543-1554.

8. Kumar H, Ahlawat VP, Yadav BS, Sehrawat SK. Response of nitrogen and zinc application on spike length, bulb production and nutrient content in tuberose (Polianthes tuberosa Linn.) cv. Double. Haryana Journal of Horticultural Science. 2004; 33(3, 4):221-223.

9. Mostafa MM, EL-haddad EH, Amar MA. Effectiveness of foliar nutrition with some micro-elements of chrysanthemum plants. Alexandria Journal of Agricultural Research. 1997; 42(1):81-93.

10. Muthumanickam D, Rajmani K, Jawaharlal M. Effect of micronutrients on flower production in Gerbera. Journal of Ornamental Horticulture. 1999; 2(2):131-132.

11. Nagaraju CG, Reddy TV, Madaiah D. Effect of N, K and multiplex on growth, production and quality harvest of field grown roses cv. Gladiator. Journal of Ornamental Horticulture. 2003; 6(4):287-279.

12. Naik PV. Effect of Micronutrients on growth, yield and quality of rose (Rosa hybrida) under greenhouse. M.Sc. thesis submitted to University of Agricultural Sciences, Banagalore, 2007.

13. Sahu MK, Kushram T, Tirkey T, Shukla N, Sharma G. Effect of $\mathrm{ZN}$, Mn, Fe sprays on growth of gerbera under polyhouse conditions. International Journal of Chemical Studies. 2017; 5(6):403-407

14. Sirin U. Effect of different nutrient solution formulations on yield and cut flower quality of Gerbera (Gerbera jamesonii) grown in soilless culture system. African Journal of Agricultural Research. 2011; 6(21):4910-4919.

15. Sujatha K, Gowda JVN, Khan MM. Effects of different fertigation levels on gerbera under low cost greenhouse. Journal of Ornamental Horticulture. 2002; 5(1):54-59.

16. Tyagi NK, Golliwar VJ, Raut PD, Thakre SA. Effect of nutrients on growth, yield and quality of gerbera Var. Ruby Red under poly house condition. Journal of Agricultural science and Technology. 2011; 36(2):299301. 